Technical note

\title{
Options for Child Benefits in Kosovo
}

\section{Synthesis of international experiences and considerations for Kosovo in response to Parliament Resolution on Child Allowances, No. 06-R-014 ${ }^{1}$}

April 10, 2019

\footnotetext{
${ }^{1}$ This technical note was prepared by Stefanie Brodmann (Sr. Economist, World Bank and Task Team Leader), Boryana Gotcheva (Consultant, World Bank), Florentin Kerschbaumer (Jr. Professional Officer, World Bank), and Erëblina Elezaj (Consultant, World Bank). The team acknowledges financial support from the Rapid Social Response Multi-Donor Trust Fund. Standard disclaimer: This technical note is a product of the staff of the International Bank for Reconstruction and Development/ The World Bank. The findings, interpretations, and conclusions expressed in this paper do not necessarily reflect the views of the Executive Directors of The World Bank or the governments they represent. The World Bank does not guarantee the accuracy of the data presented in this work.
} 


\section{Main messages}

Kosovo is the second poorest country in Europe, after Moldova, with one in five Kosovars living in poverty. Improved economic conditions in the country have yet to translate into significant poverty reduction. The poor are overrepresented in households headed by women, in households in which the head has not completed secondary education, in households with more children, in larger households (with peak in households of 5 members), and among people whose main source of income is social assistance, specifically Category I Social Assistance Scheme beneficiaries.

Child benefits are one of the most common components of the family benefit systems in the European countries, and worldwide. They are part of a broader set of measures aimed at reducing poverty and vulnerability of families with children. Practically all EU countries and five out of six Western Balkan countries (including Kosovo through a child supplement paid to social assistance recipient families with children) have monthly child benefits, either means-tested or universal, or a combination of both. Worldwide, there is a trend toward targeting child benefits to poor families or to both poor and middleincome families and, at the same time, curtailing coverage of wealthier families. In parallel, child benefits in both developed and developing countries are increasingly conditional on school enrollment, regular school attendance and/or compliance with other conditions on behalf of the benefit recipient families.

The Social Assistance Scheme is Kosovo's overarching program for protection against poverty of various vulnerable groups. Beneficiary families of the Social Assistance Scheme receive a child supplement for each child. On November 7, 2018, the Parliament of the Republic of Kosovo adopted a resolution calling on the Government of Kosovo to draft legislation for a state budget financed child benefit, "considering criteria such as family income, employment status of parents, and children's age". This note provides an overview of international experiences with child benefits and uses data from the Kosovo household budget survey to assess the impact of various options for protecting children against poverty. To avoid duplicating the existing child supplement, the targeting mechanism and implementation rules for any new child benefit should, at the very least, be coordinated with the targeting design and implementation arrangements of the Social Assistance Scheme.

The main findings and recommendations of this note are:

- Reforming the Social Assistance Scheme is the most viable and economic option for tackling child poverty in Kosovo, as opposed to a stand-alone child benefit scheme or a child supplement to the Social Assistance Scheme in its current form.

- A reform of the Social Assistance Scheme (without an increase in the budget) would increase the number of families with children that are covered by the Scheme by more than 25 percent. Under a budget neutral reform that entails an elimination of the categorical filters, introduction of a new combined means and proxy means test (new targeted scheme), and a revision of the equivalence scales, the poverty gap would be reduced by 12 percent compared with the current Social Assistance Scheme. This implies that a reform of the Social Assistance Scheme would not only significantly reduce child poverty but also reduce the adverse incentives and poverty traps that many existing benefit-receiving families currently face. Moreover, it would also increase the effectiveness of Kosovo's social assistance system as more money would be devoted to poor and vulnerable families in the country.

- Increasing the current child supplement by EUR 10 per child for families covered by the Social Assistance Scheme, without reforming the Social Assistance Scheme, would also contribute to poverty reduction for families: the poverty gap would be reduced by 6 percent but at a significantly higher cost than a budget-neutral reform of the Social Assistance scheme. Therefore, this option 
would be significantly less cost-effective and reach a significantly lower number of children (25 percent less than under a budget neutral reform of the Social Assistance Scheme).

- Reforming the Social Assistance Scheme and increasing the budget would further reduce poverty by increasing coverage of the poor. Increasing the budget and allocating a share as a child supplement to poor children in SAS families and as a child benefit to children in non-SAS families, would significantly reduce the poverty gap. The estimated poverty gap reduction would be 26 percent in the case of a budget increase of EUR 17 million, of which EUR 7 million are allocated among children in SAS families, and 25 percent if the budget is the same and EUR 7 million of it are allocated among children in families which do not receive SAS.

- The Government of Kosovo is considering a comprehensive reform of the social assistance system, including a common targeting mechanism for numerous means-tested programs. This would improve targeting accuracy and reduce the high administrative burden associated with using several beneficiary identification methods in parallel. A new targeting methodology could apply different eligibility thresholds/cutoff scores for different poverty targeted programs; thus, less rigorous eligibility rules could guarantee a higher coverage of the child benefit beyond the Social Assistance Scheme recipient families. As an example, reforming the Social Assistance Scheme, increasing its budget by EUR 10 million, and allocating an additional EUR 7 million to poor children who are not covered by the Social Assistance Scheme, would result in an estimated increase in coverage of the poor to 65 percent, assuming a child benefit of EUR 10 per child per month, reaching over 150, $000(227,000)$ children; or - assuming a child benefit of EUR 5, would result in an estimated increase in coverage of the poor to 80 , reaching over 227,000 children.

- Simulations confirm that a universal child benefit would not be the best policy choice for Kosovo. A universal child benefit would have a small progressive beneficiary incidence: less than half of the child benefit recipients would belong to the poorest 40 percent of the welfare distribution and only a quarter to the poorest 20 percent. A universal child benefit would be very costly. The estimated program budget of a universal child benefit if it amounted to EUR 10 per month and was given to all children between 0 and 16 years of age, would be as high as around EUR 60 million per annum for 2019-2021, more than twice the average annual spending on the Social Assistance Scheme for 2008-2017, and close to the generous amount spent on war veteran pensions. 


\section{Context for the introduction of a child benefit in Kosovo}

The Republic of Kosovo is considering the introduction of a child benefit; the details of the scheme are yet to be determined. The Parliament of the Republic of Kosovo adopted on November 7, 2018, a resolution calling on the Government of Kosovo to draft legislation for a state budget financed child benefit and to begin implementation in 2019. The resolution does not provide details about the design of the future child benefit; it specifies only the basic principle that the child benefit should be determined "considering criteria such as family income, employment status of parents, and children's age" ${ }^{2}$.

Historically, a monthly child benefit was not envisaged as a stand-alone benefit in the architecture of Kosovo's social assistance which was set in the beginning of the $2000 \mathrm{~s}^{3}$. Such a benefit was subsequently built into the design of the Social Assistance Scheme (SAS) with introduction of a supplement of EUR 5 per child per month for each child in a SAS recipient family. The SAS is Kosovo's overarching program for protection against poverty of various vulnerable groups, including families with children. From this perspective a new child benefit should take into consideration the design of the SAS to avoid duplicating the already existing child supplement, and its targeting and implementation mechanisms should be coordinated and aligned with the design and implementation arrangements of the SAS scheme.

Having two or more children increases the respective household's or family's risk for poverty. According to Kosovo's most recent poverty profile ${ }^{4}$, the poverty rate among families with one or two children is similar to the average poverty headcount rate of 17.6 percent. The poverty rate among families with three and more children, however, is 22.2 percent and thus significantly higher than the average poverty headcount rate. High poverty rates are also observed among households headed by women (23.7 percent) and larger households (the peak being at five members with 20.6 percent) ${ }^{5}$. These are presumably family/household configurations with more children. The poverty rate for students and pupils is also higher than the average.

The SAS has many inbuilt features that severely limit its poverty-reduction impact for families with children and pose adverse labor market incentives for working-age family members. The current SAS legislation has inbuilt categorical restrictions and near-exclusionary filters ${ }^{6}$ which restrict access to SAS to families with at least one child under the age of five (Category II). There is no evidence to suggest that the cost of childrearing decreases after that age. Excluding families with older children only constrains the povertyreduction impact of the scheme. Furthermore, SAS benefit conditionality for Category II requires all but one household member to be classified as dependent, and the single able to work member to be

\footnotetext{
2 Parliament Resolution on Child Allowances, No. 06-R-014.

3 The key structural components of social assistance in Kosovo were introduced with a UNMIK (United Nations Interim Administration Mission in Kosovo) resolution of 2000, followed by Law No. 2003/15 on the Social Assistance Scheme in Kosovo, Law No. 2003/23 on Disability Pensions in Kosovo and Law No. 02/L-17 of 2005 on Social and Family Services. The key structural components of social assistance include: (i) last resort income support program - the Social Assistance Scheme (SAS); (ii) material support for foster families; (iii) assistance for exceptional needs; (iv) energy/electricity subsidy; (v) material support for families with children (of ages 0-18 years) with permanent disability; (vi) social and family services.

${ }^{4}$ Kosovo Agency of Statistics and the World Bank. Consumption Poverty in the Republic of Kosovo 2012-2015, April, 2017. In 2015, the national poverty line was $€ 1.82$ per adult equivalent per day and the extreme poverty line $€ 1.30$ per adult equivalent per day. 5 Ibid.

${ }^{6}$ According to Law No. 2003/15 on the Social Assistance Scheme in Kosovo, eligible for SAS are two categories: Category I - all family members are dependent (persons over 18 years of age with permanent and severe disabilities rendering them unable to work, persons 65 years of age and older, full-time caregivers of person(s)or of children under the age of five, persons up to 14 years of age, persons between the age of 15 and 18 (inclusive) who are in full-time education, and single parents with at least one child under the age of 15) and none is employed; and Category II - families can have one family member who is able to work but registered as unemployed with the Employment Office. All other family members must be dependent. In addition, the family must be parenting at least one child under the age of 5 or providing permanent care for an orphan under the age of 15.
} 
unemployed ${ }^{7}$. This poses adverse labor market incentives for families with children as they often have more than one able to work adult family member. Hence, they can only receive SAS benefits if the second and next adult family members acquire the status of dependent, that is, fulfill Category I eligibility criteria. To the extent that this discourages their labor market participation, it creates a substantive poverty trap. If the child benefit is incorporated in the SAS and the current targeting mechanism is preserved, the exclusion will be replicated and reproduced, and the impact of the child benefit on poverty reduction would be undermined.

Reforms to the SAS would reduce its adverse incentives and enhance its poverty-reducing impact. As suggested in a recent World Bank report ${ }^{8}$, a reform of the SAS would involve replacing the current SAS design ${ }^{9}$ with a new design characterized by two main features:

- A two-stage poverty test with sequential application of a means test and a proxy-means test. At stage one, the means test is an assessment of income from economic activity, social protection schemes of the Ministry of Labor and Social Welfare (MLSW), other government grants and subsidies, and other verifiable sources. At stage two, a new proxy-means test (PMT) is applied to applicants/households that fall below the threshold of the means test. The new PMT is an assessment of proxy indicators of household wealth and includes observable indicators of housing conditions, ownership of assets, and demographic characteristics of households. The indicators and their weights/coefficients are determined based on econometric analysis of household survey data, and households are assigned scores according to which they either qualify or do not qualify for the SAS.

- New 'optimal' benefit scales based on simulations to maximize the impact of the SAS scheme on poverty reduction, given a certain budget. They replace the current implicit equivalence scales which assume disproportionate economies of scale (i.e., the benefit increases only marginally with household size).

\footnotetext{
${ }^{7}$ Law No. 2003/15 on the Social Assistance Scheme and Law No. 04/L-096 on Amending and Supplementing the Law No. $2003 / 15$ on the Social Assistance Scheme.

8 World Bank. 2019. Kosovo Social Assistance Scheme Study, March 2019.

9 The current SAS design involves categorical identification with application of exclusionary filters (for defining Category I and Category II SAS beneficiaries) and a questionnaire combining income and proxy-means indicators which can be exclusionary and are not based on a rigorous econometric model that links it to poverty. It also involves equivalence scales which are not favorable for larger households as the benefit levels increase only marginally with household size.
} 
Two basic models of child benefits worldwide: universal and targeted to the poor

There are two prevailing models of child benefits or allowances ${ }^{10}$ worldwide: universal and targeted to the poor. A universal child benefit is granted to every child irrespective of the income, assets and employment status of the family in which this child is raised. Its proponents emphasize advantages such as promoting horizontal equity and reducing income inequality which could arise from the costs of parenting; also, administrative simplicity and absence of moral hazard. Opponents point to its high cost and low effectiveness in poverty reduction. A targeted child benefit is granted based on specific poverty-related criteria, usually a means test, or other type of poverty test. Its proponents emphasize its capacity to target those most in need and to effectively reduce poverty. The strengths and weaknesses of these models are summarized in Table 1.

Table 1: Main characteristics (strengths and weaknesses) of universal and poverty targeted child benefits

\section{Universal child benefit}

Ensures basic income security for all children irrespective of differences in need

Costly - requires significant resources to support all children with a meaningful benefit; alternatively small benefits for all would have a meager impact on poverty reduction

Horizontal equity - all children are treated in the same manner and the state recognizes the contribution made by all parents to the task of rearing children

Absence of moral hazard - the receipt of benefits regardless of parents' employment or income does not contribute to unemployment or poverty trap; receiving benefits on top of in-work income does not create a disincentive to work

Administrative simplicity and efficiency

\section{Poverty targeted child benefit}

Provides income security for a targeted but narrower group of children in need

Cost effective - results in a larger reduction in poverty with less spending by focusing the resources to the poorest, underprivileged and needy

Aims at vertical equity - only children who have less (are poor) receive child benefit

High marginal tax rates associated with income-tested benefits could reduce incentives to enter and stay in employment; also, there may exist an incentive at the margin not to earn more or save if this meant loss of the child benefit

Administratively complex beneficiary identification and increasing complexity as family structures become more fluid

Full, or close to full, take-up due to easy verification of entitlement
Low take-up due, in the case of administrative barriers, to access, stigma, lack of information, etc.

Source: Compiled after: Child Benefits in Central and Eastern Europe. A comparative review / Jonathan Bradshaw, Kenichi Hirose; International Labor Organization, ILO DWT and Country Office for Central and Eastern Europe. Budapest: ILO, 2016 and Child benefits in the European Union, CPAG Poverty Magazine 139.

${ }^{10}$ The terms 'monthly child benefit' and 'monthly child allowance' are used as synonyms interchangeably. 
Possible child benefit design scenarios for Kosovo

Poverty targeted child benefit

The Government of Kosovo is considering the introduction of a poverty targeted child benefit. The entry point for selecting design scenario(s) for a new child benefit in Kosovo is the provision in the Parliament's resolution stating that the child benefit should be determined by, inter alia, family income (i.e., be means tested). In general, family benefits, including monthly child benefits, are 'loaded' with multiple objectives such as reducing poverty among families with children, compensating parents for some of the costs of child rearing, and even birth promotion. While there is no robust empirical evidence that the monthly child benefits impact the decision to have more children, they are increasingly considered a viable instrument for reducing poverty among children and boosting investment in human capital ${ }^{11}$. The long-term social and economic costs of child poverty are estimated as high ${ }^{12}$. To the extent that child benefits contribute to reducing these costs, they could have a large financial return. As evident from Kosovo's poverty profile, in the case of Kosovo, there is an argument in favor of greater financial protection for poor children.

Greater financial protection for poor children in Kosovo could be achieved in several ways:

Option 1: Reforming the Social Assistance Scheme with variations of reform options with respect to financing (budget neutral option and option with increased budget).

\section{Option 1a: Reforming the Social Assistance Scheme without increasing its budget (budget neutral)}

The key elements of the proposed reform involve a new poverty test, elimination of the categorical 'filters' (Category I and Category II), and a new equivalence scale which is 'optimal' in that it has the strongest effect on poverty given the available budget. ${ }^{13}$ This new equivalence scale is more favorable for larger families; it assigns a weight of 1 to the first adult in the family, a weight of 0.25 for each additional adult, and a weight of 0.2 for each child. With this new optimal equivalence scale, the 5 EUR child supplement will be removed. Reforming and modernizing the SAS to eliminate discrimination in program design, promote inclusion, expand coverage, and reduce poverty of social assistance recipients would bring many benefits through poverty reduction. The reform would benefit specifically those who are excluded from receiving social assistance under its current design (i.e., those who do not meet the strict eligibility criteria), namely: poor families with children in which all children are older than 5 years; and families who have more than one able-bodied, but not working, adult member. Through a reform of the SAS, poor families with children would be more adequately covered with social assistance.

\section{Option 1b: Reforming the Social Assistance Scheme and increasing budget}

Ideally, a reform of the SAS as outlined above would go hand in hand with rationalization of funds within the social transfers, and reallocation from categorical benefits towards programs targeted to the poor. Any increase in the budget for the reformed SAS would increase the number of children receiving SAS due to the new poverty targeting mechanism and increase the transfer amount to families of children due to the optimal equivalence scale.

\footnotetext{
11 The number of countries which provide poverty tested child benefits and also link their provision to conditions like school enrollment and attendance, vaccinations, and regular medical checks of young children with primary health providers.

12 For example, in studies undertaken in the UK, these costs are projected to be over GBP 35 billion, or 3 percent of GDP by 2020. See: Child Benefits in Central and Eastern Europe. A comparative review / Jonathan Bradshaw, Kenichi Hirose; International Labor Organization, ILO DWT and Country Office for Central and Eastern Europe. Budapest: ILO, 2016.

13 World Bank. 2019. Kosovo Social Assistance Scheme Study, March 2019.
} 
Without reforming the SAS, there is little room for increasing support for children. It would only be possible to: (i) increase the nominal amount of the child supplement, or (ii) differentiate it based on the child's age or birth order. Any increase in the budget for the child supplement without a reform of the SAS scheme would preserve the scheme's limitations - its limited coverage and significant exclusionary errors would apply equally to the child supplement. The absence of a rule-based approach to determining the amount of the child supplement, as opposed to an equivalence scale, would undermine equity (both within the SAS and child supplement scheme, and across the groups of poor who receive SAS and poor who do not receive SAS). The possible differentiation of the child supplement (e.g., by age or birth order) would not increase the coverage but would, however, unnecessarily increase administrative costs.

\section{Option 3: New child benefit which is coordinated with the Social Assistance Scheme in terms of beneficiary identification methodology}

This is not a stand-alone option per se, rather a next step in the development of Option 1, in which the child benefit can be provided both to poor and possibly low-middle income families that do not qualify for SAS. Within a national social assistance system, the child benefit which is provided based on a means test or another form of poverty test, could be separate and independent from the poverty test used by other schemes (primarily the SAS scheme in the case of Kosovo). Alternatively, the child benefit's targeting method could be aligned with and coordinated in one way or another with the targeting methodology for the SAS. Both approaches have pros and cons, but there are strong arguments in favor of setting up an overarching and harmonized poverty test (that involves family incomes and assets, and other family characteristics) with possibilities for variations in certain elements of the targeting formula (such as eligibility thresholds, proxy means test scores, demographic and/or categorical criteria). The implementation of such an approach is becoming increasingly feasible with enhancements of the social assistance management information systems and, in particular, the SAS management information system (MIS), and even more so in the case of a future social registry for identification of the poor and vulnerable individuals and families. This approach is viable and can be applied in Kosovo after reforming the SAS. The same scoring formula used for SAS beneficiary identification, but with less rigorous access thresholds/score, could be used to identify children eligible for the child benefit who live in poor but non-SAS recipient families, or in low-middle income families. 


\section{Simulation results}

To assess the relative importance of the various recommendations for reform, this section uses microsimulations to evaluate the impact of modifications to the existing SAS. ${ }^{14}$

\section{Option 1: Reforming the Social Assistance Scheme}

\section{Reforming the SAS would be the most efficient solution to address child poverty in Kosovo.}

When simulating a poverty targeted child benefit, the current SAS with its current targeting mechanism and benefit level (EUR 60 for the first adult, EUR 22.5 for the second, EUR 7.5 for each additional household member, plus EUR 5 for each child) is used as a baseline. Then the child benefit performance (in terms of reduction of poverty headcount and poverty gap) is simulated with the new targeting criteria as proposed for the reform of the SAS and an 'optimal' equivalence scale ${ }^{15}$ that is chosen by maximizing the new scheme's impact on poverty reduction. Table 2 summarizes the simulated impact of all reform options which are discussed further in the note: the changes in SAS performance (in terms of targeting accuracy, adequacy, and coverage); the changes in the number of SAS direct and indirect beneficiaries; and the number of children in and outside SAS families who would benefit from each of the reform options.

Table 2: Changes in poverty impact, performance indicators and beneficiary numbers under different SAS and child benefit design and spending scenarios

\begin{tabular}{|c|c|c|c|c|c|c|c|c|c|c|c|}
\hline Scheme & $\begin{array}{l}\text { Change in } \\
\text { Head-count } \\
\text { (pp) }\end{array}$ & $\begin{array}{l}\text { Change in } \\
\text { Poverty } \\
\text { Gap (pp) }\end{array}$ & $\begin{array}{l}\text { Change in } \\
\text { Head- } \\
\text { count } \\
\text { (percent) }\end{array}$ & $\begin{array}{c}\text { Change in } \\
\text { Poverty } \\
\text { Gap } \\
\text { (percent) }\end{array}$ & $\begin{array}{l}\text { Targeting } \\
\text { Accuracy }\end{array}$ & $\begin{array}{c}\text { Benefit } \\
\text { Adequacy }\end{array}$ & $\begin{array}{l}\text { Coverage } \\
\text { of poor }\end{array}$ & $\begin{array}{c}\text { Number of } \\
\text { beneficiaries }\end{array}$ & $\begin{array}{l}\text { Number } \\
\text { of } \\
\text { Families }\end{array}$ & $\begin{array}{l}\text { Number of } \\
\text { children in } \\
\text { SAS }\end{array}$ & $\begin{array}{c}\text { Number } \\
\text { of } \\
\text { children } \\
\text { not in } \\
\text { SAS } \\
\end{array}$ \\
\hline Current Scheme & 1.776 & 1.197 & 0 & 0 & $64 \%$ & $39 \%$ & $26 \%$ & 106,416 & 28,276 & 55,285 & 0 \\
\hline $\begin{array}{l}\text { Current Scheme with EUR } \\
15 \text { instead of } 5 \text { per child }\end{array}$ & 2.06 & 1.385 & $2 \%$ & $6 \%$ & $64 \%$ & $47 \%$ & $26 \%$ & 106,416 & 28,276 & 55,285 & 0 \\
\hline $\begin{array}{c}\text { Reformed SAS: optimal } \\
\text { benefit level }\end{array}$ & 3.642 & 1.965 & $13 \%$ & $12 \%$ & $76 \%$ & $53 \%$ & $40 \%$ & 150,648 & 22,289 & 69,730 & 0 \\
\hline $\begin{array}{l}\text { Reformed SAS: optimal } \\
\text { benefit level plus EUR } 7 \\
\text { million } \\
\end{array}$ & 4.215 & 2.173 & $16 \%$ & $18 \%$ & $71 \%$ & $53 \%$ & $44 \%$ & 162,582 & 26,330 & 80,172 & 0 \\
\hline $\begin{array}{l}\text { Reformed SAS: optimal } \\
\text { benefit level plus EUR } 10 \\
\text { million }\end{array}$ & 4.348 & 2.216 & $17 \%$ & $20 \%$ & $68 \%$ & $53 \%$ & $46 \%$ & 174,649 & 28,547 & 85,969 & 0 \\
\hline $\begin{array}{l}\text { Reformed SAS: optimal } \\
\text { benefit level plus EUR } 10 \\
\text { million, plus EUR } 7 \text { million } \\
\text { for children }\end{array}$ & 4.759 & 2.407 & $20 \%$ & $26 \%$ & $68 \%$ & $61 \%$ & $46 \%$ & 174,649 & 28,547 & 85,969 & 0 \\
\hline $\begin{array}{c}\text { Reformed SAS: optimal } \\
\text { benefit level plus EUR } 10 \\
\text { million, plus EUR } 7 \text { million } \\
\text { for children not in SAS (10 } \\
\text { EUR/child) }\end{array}$ & 4.912 & 2.39 & $21 \%$ & $25 \%$ & $49 \%$ & N/A & $65 \%$ & 334,893 & 56,454 & 85,969 & 65,211 \\
\hline $\begin{array}{c}\text { Reformed SAS: optimal } \\
\text { benefit level plus EUR } 10 \\
\text { million, plus EUR } 7 \text { million } \\
\text { for children not in SAS (5 } \\
\text { EUR/child) }\end{array}$ & 4.884 & 2.383 & $20 \%$ & $25 \%$ & $40 \%$ & N/A & $80 \%$ & 506,561 & 86,843 & 85,969 & 141,108 \\
\hline
\end{tabular}

Source: World Bank estimations using HBS 2016.

\footnotetext{
${ }^{14}$ A detailed description of the data and methodology can be found in: World Bank. 2019. Kosovo Social Assistance Scheme Study, March 2019.

${ }^{15}$ The optimal scale is the following: Benefit optimal scale $=60 *[1+\max ($ nadult $-1,0) * 0.25+$ nchildren $* 0.2]$
} 
Option 1a: Reforming the Social Assistance Scheme without increasing its budget (budget neutral)

The number of children in SAS recipient families will increase by over a quarter only by reforming the SAS (with the new beneficiary identification method and revised equivalence scale), even without any budget increase.

This reform option is budget neutral (highlighted in Table 2 in orange) and any changes in SAS performance would come solely from changes in its design. Such changes include:

- The number of children in SAS recipient families would increase by 26.1 percent (from 55,285 to 69,730 children), or from around 9 percent to around 11.3 percent of Kosovo's child population under the age of $19^{16}$.

- Poverty would be reduced significantly - the poverty headcount rate by 12 percent and the poverty gap by 13 percent compared to the baseline scenario (current SAS scheme including a child supplement of EUR 5 per month per child up to the age of 18).

- The targeting accuracy (share of SAS budget accrued to the poorest population quintile) would increase to 76 percent (from the current 64 percent).

- The SAS benefit adequacy would also increase notably - from 39 percent to 53 percent of the consumption of the poorest quintile.

- The coverage of the poorest quintile would increase from 26 percent to 40 percent.

- The number of direct and indirect beneficiaries would increase from 106,416 to 150,648. At the same time, this effect would lead to a decrease in the number of SAS beneficiary families (SAS direct beneficiaries) from 28,276 to 22,289. Figure 1 presents the expected changes in numbers of beneficiaries under different reform options for the SAS and child benefits.

Figure 1. Changes in number of SAS recipient families and beneficiaries under different reform options

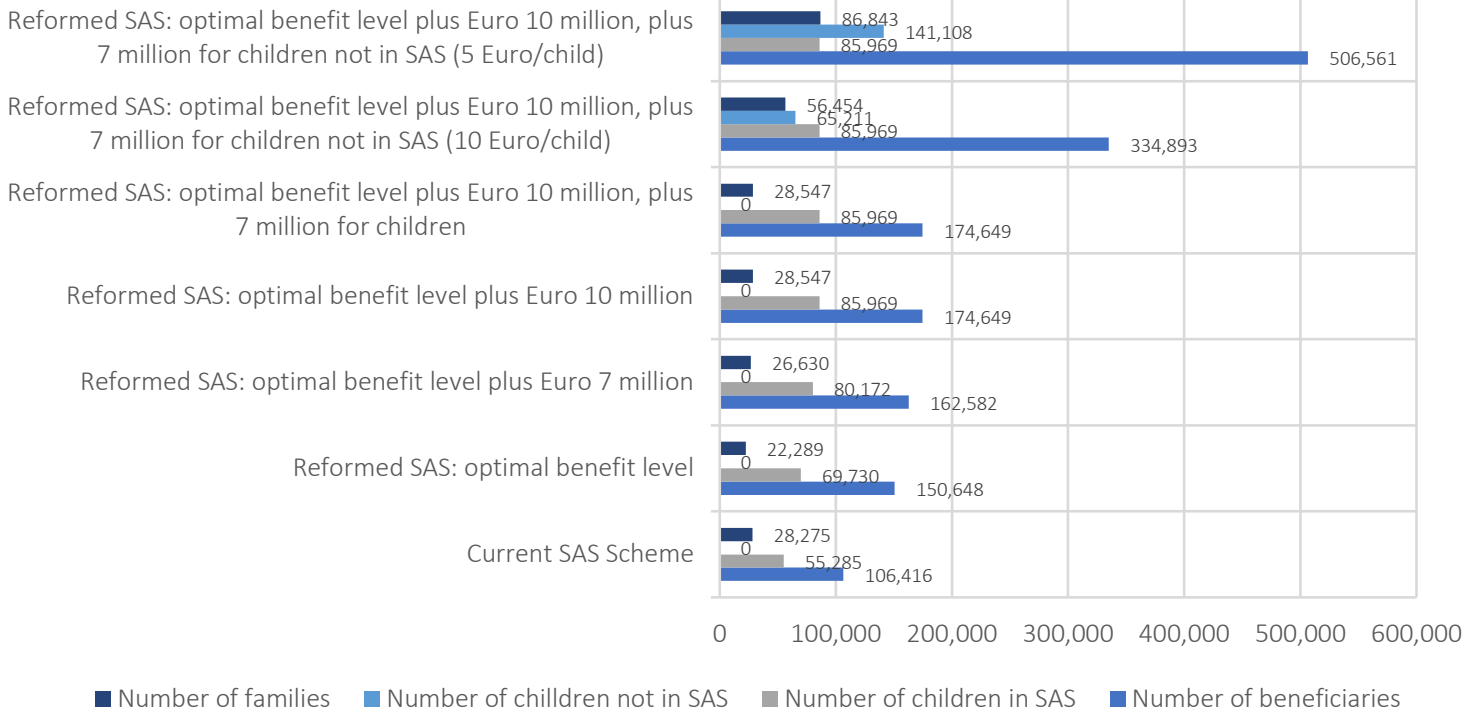

Source: World Bank estimations using HBS 2016.

\footnotetext{
16 The number of children $0-19$ is 617,558 , according to the population projections of the Kosovo Agency of Statistics (medium variant) for 2017.
} 
The allocation of additional budget to the reformed SAS would be cost-effective in terms of poverty reduction; the SAS performance in terms of targeting will remain good, and - most importantly - would result in a significant increase in the number of children who would benefit from the reformed SAS.

The simulated results of reforming the SAS together with increasing its budget (two sub-options: (i) budget increase by EUR 7 million and (ii) budget increase by EUR 10 million, respectively; Table 2, highlighted in blue) indicate that:

- The number of children in SAS beneficiary families would increase to 80,172 (by 45 percent, to 13 percent of the child population under the age of 19) in case of budget increase of EUR 7 million, and to 85,969 (by 55.5 percent, to 13.9 percent of the child population under 19 years of age in Kosovo) if the budget is increased by EUR 10 million.

- The SAS coverage would increase - respectively to 44 percent and 46 percent of the poorest quintile, compared to 40 percent under the budget neutral option. Coverage of the reformed SAS under the financing scenarios discussed above, as well as under the budget neutral scenario, and compared to the performance of the current SAS are presented in Figure 2 (right).

- The SAS benefit adequacy would remain high, similarly to the budget neutral reform option (at 53 percent of the consumption of the poorest quintile).

- The SAS benefit incidence (share of SAS budget going to the poorest quintile) would decline to 68 percent and 71 percent compared to 76 percent in the budget neutral option (Figure 2, left). There is a tradeoff between the targeting accuracy and coverage. Increase in coverage increases also the probability of inclusion errors. In this case, despite the decline, targeting accuracy remains high.

- The poverty impact of the reformed and more generously financed SAS would increase to 16-17 percent of poverty headcount reduction and 18-20 percent of poverty gap reduction compared to the baseline (current SAS scenario). The schedules of reduction in the poverty headcount and poverty gap under different SAS design and spending scenarios are compared in Figure 4.

Figure 2. Comparison between the targeting accuracy (left) and coverage (right) of the reformed SAS (without budget increase and with two options of increased financing) compared to the current SAS

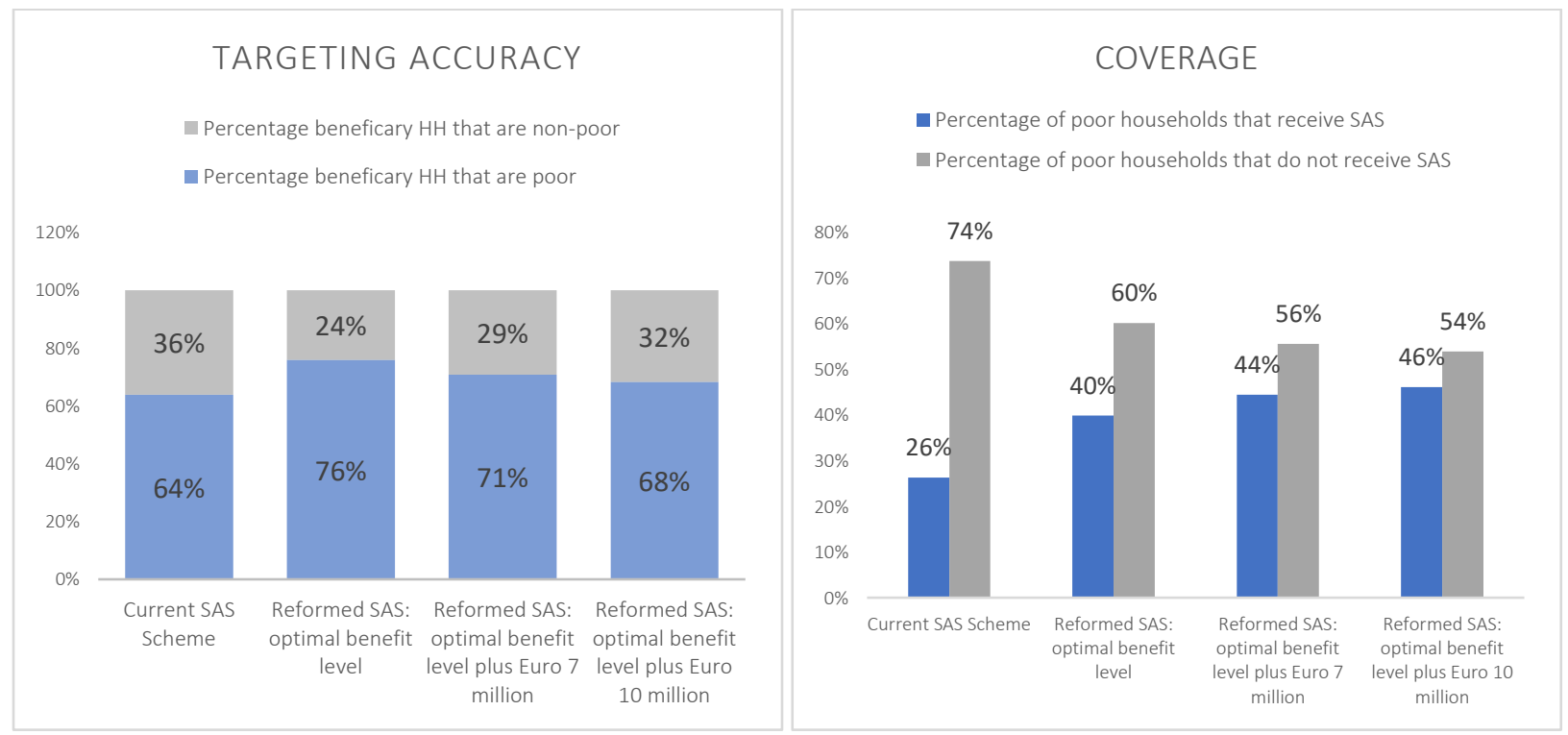

Source: World Bank estimations with ADePT using HBS 2016. 
Increasing the current child supplement by EUR 10 per child for families covered by the SAS, without reforming the SAS, would also contribute to poverty reduction for families: the poverty gap would be reduced by 6 percent and the poverty headcount by 2 percent, but at a significantly higher cost than a budget-neutral reform of the SAS. Therefore, this option would be significantly less cost-effective and reach a significantly lower number of children (26 percent less than under a budget neutral reform of the SAS). Other parameters of the SAS would remain unchanged, only SAS adequacy would increase from the current 39 percent to 47 percent of the post-transfer value of consumption in the poorest quintile.

Option 3: Reforming the SAS and increasing the SAS budget with variation based on how the budget increase is allocated

Reforming the SAS and increasing the budget would further reduce poverty by increasing the coverage of the poor. Increasing the budget and allocating a share as a child supplement would significantly reduce the poverty headcount rate and the poverty gap.

These simulations assess the impact of additional financing for the reformed SAS at the amount of EUR 17 million and consider three options for allocating this financing for all beneficiaries, children in SAS beneficiary families and also children outside SAS beneficiary families. The simulations look at three suboptions for allocation of additional financing to the reformed SAS (Table 2, highlighted in green), namely:

- Option 3a: reformed SAS with optimal benefit level plus EUR 10 million, plus EUR 7 million allocated only for children in SAS recipient families;

- Option 3b: reformed SAS with optimal benefit level plus EUR 10 million, plus EUR 7 million for children not in SAS (10 EUR/child); and

- Option 3c: reformed SAS with optimal benefit level plus EUR 10 million, plus EUR 7 million for children not in SAS (5 EUR/child).

The changes in SAS beneficiaries under Options $3 a-3 c$ are presented in Figure 1. The most significant increase in the numbers of beneficiaries would be achieved if the eligibility for the child benefit is "opened" for children living outside SAS recipient families (Options $3 b$ and 3c), and especially in case of a lower level benefit (EUR 5, Option 3c) per child per month. This approach would allow extending the child benefit to over 227 thousand children (36.8 percent of all children in Kosovo 0-19 years old), including 85,969 children in SAS beneficiary families and 141,108 children who are not in SAS families. Option 3b would allow covering of 85,969 children in SAS beneficiary families and 65,211 children who are not in SAS families, or 150,180 children in total (24.3 percent of all children in Kosovo 0-19 years old). Option 3a, on the other hand, would not increase the number of eligible children; eligibility will remain restricted only to children in SAS recipient families. It would however have a significant impact on increasing benefit adequacy - to over 60 percent of the post-transfer consumption of its recipients.

The coverage of the poor (share of recipients in the bottom consumption quintile) would be also significantly higher when the child benefit is extended to children beyond SAS recipient families, as high as 80 percent when the benefit level is set at EUR 5 per child per month (Option 3c), and 65 percent when the benefit level is EUR 10 per child per month (Option 3b) (Figure 3, right).

Conversely, the targeting accuracy would remain highest when the additional budget of EUR 17 million is allocated to the reformed SAS plus EUR 10 million, and plus EUR 7 million for children only in SAS recipient families (Option 3a) (Figure 3). This option would achieve high targeting accuracy (68 percent of the poorest quintile) but this would be the effect of not expanding coverage - about 40 percent of the poor will be covered. The other two options will compromise on targeting accuracy (under Option 3b, 50 percent 
of the SAS and child benefit budget will accrue to the poorest 20 percent of the population; under Option $3 c$, only around 40 percent of the budget will be allocated to the poor) while coverage of the poor would expand significantly.

The impact of SAS reform options on poverty, including Options 3a-3c, are presented in Figure 4. In all three cases of budget increase by EUR 17 million, the reduction in poverty is impressive: the poverty headcount rate would be reduced by 20-21 percent, the poverty gap by 25-26 percent.

Figure 3. Targeting accuracy (left) and coverage (right) of the reformed SAS under different financing scenarios
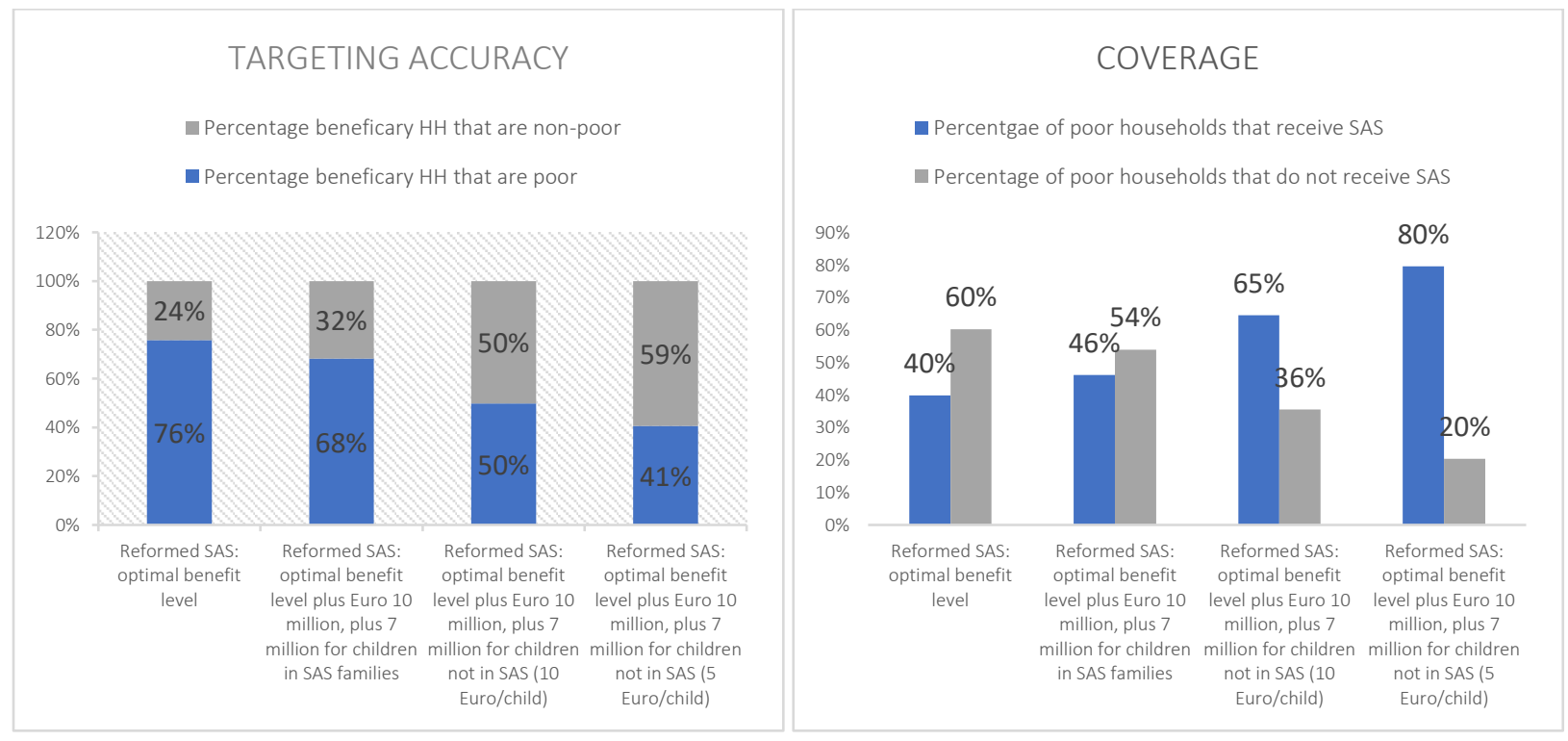

Source: World Bank estimations with ADePT using HBS 2016.

Figure 4: Reduction in the poverty headcount and poverty gap for families with children under different SAS design and spending scenarios

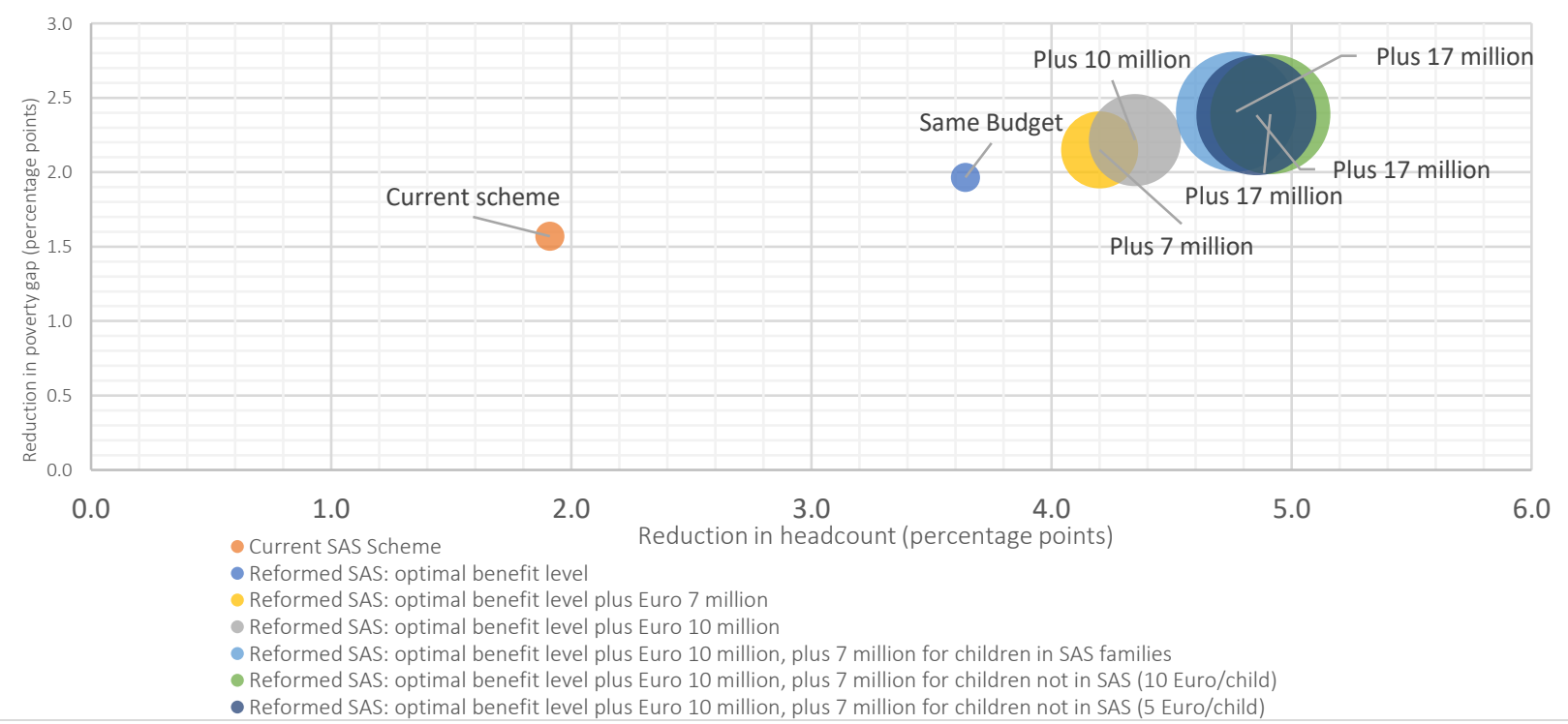

Source: World Bank estimations using HBS 2016. 


\section{Comparisons with a simulated Universal Child Benefit}

A universal child benefit does not emerge as the best policy choice for Kosovo.

Simulations suggest that:

- A universal child benefit will have small progressive benefit incidence: less than half of the budget would be allocated to the bottom 40 percent of the welfare distribution. Conversely, over half of the budget would be 'wasted' on non-poor and affluent families (Figure 5);

- Similarly, a universal child benefit would have small progressive beneficiary incidence: less than half of the child benefit recipients would belong to the poorest 40 percent of the welfare distribution and only a quarter to the poorest 20 percent;

- A universal child benefit would be costly. The estimated program budget of a universal child benefit if it amounted to EUR 10 per month and was given to all children 0-16 years of age, would be as high as around EUR 60 million per annum for 2019-2021 - more than 2 times the average annual spending on the Social Assistance Scheme for 2008-2017, and close to the generous amount spent on war veteran pensions.

Figure 5: Simulated beneficiary incidence (left) and benefit incidence (right) of a universal child benefit, by consumption quintiles (\%)
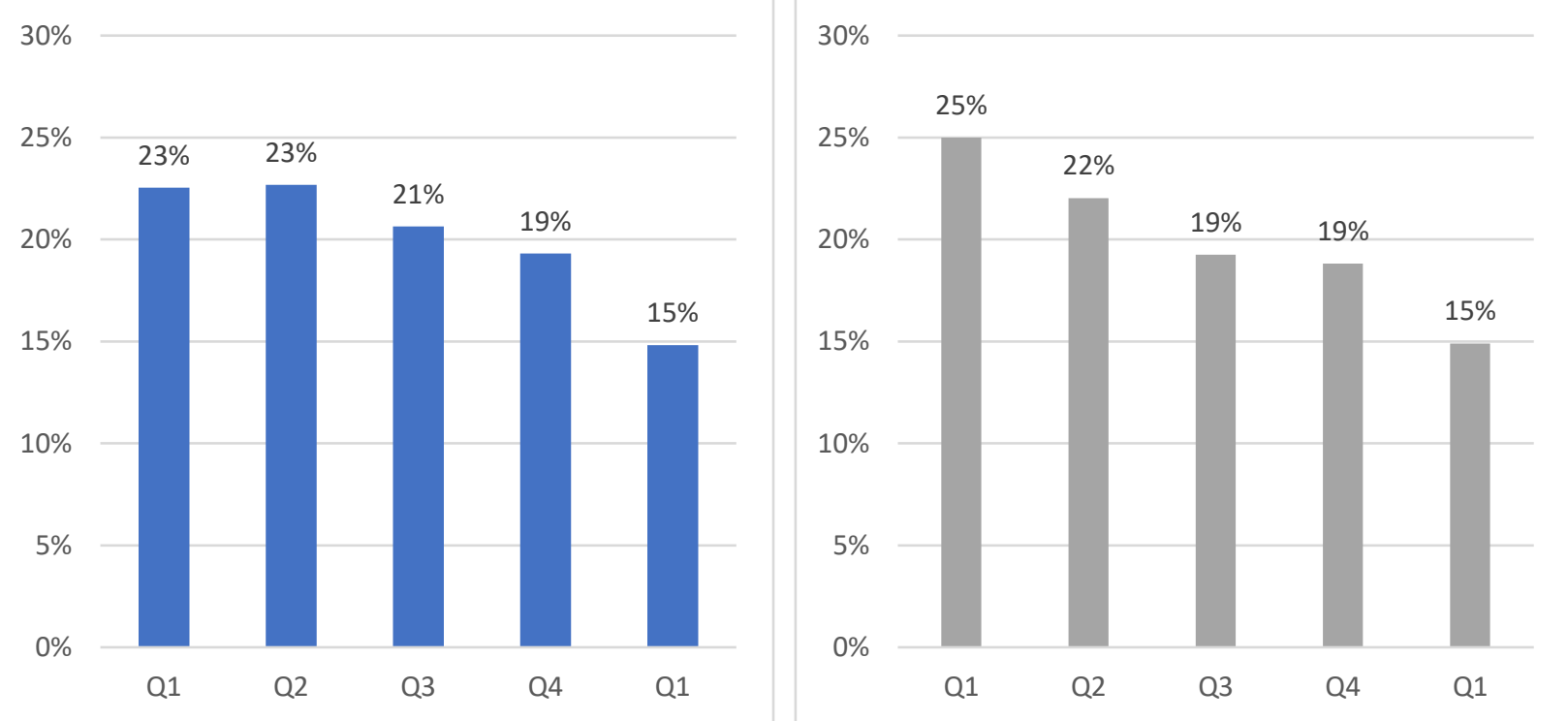

Source: World Bank calculations using HBS 2016. 
Monthly child benefits are one of the most common elements of the family benefit systems in the European countries, and worldwide. They are a part of a broader set of measures that aim at reducing poverty and vulnerability of families with children ${ }^{17}$. All EU and EFTA member states deliver monthly child benefits in cash, except for Iceland where support for families with children exists only in the form of tax refunds. The Western Balkan countries also have monthly child benefits, except for Albania. In Kosovo, as already mentioned, the child benefit exists as a child supplement within the SAS scheme. The main characteristics of child benefits in the EU, EFTA and Western Balkan countries are summarized in Table 2.

Roughly half (13 out of 28) EU Member States have universal child benefits, and in 3 of these cases the universal child benefit includes certain elements of means-testing ${ }^{18} .12 \mathrm{EU}$ Member States have only means-tested child benefits, and 3 countries have two child benefits, one of them universal and the other means-tested. The child benefits are means-tested in the four Western Balkan countries where they exist as stand-alone programs (Bosnia and Herzegovina, Montenegro, North Macedonia, and Serbia). Usually the means test for the child benefit is less rigorous than the means test for the last-resort income support benefit, which is usually narrowly targeted while the child benefit is designed to reach not only low but also (part of) middle-income families. Worldwide, there is a trend toward targeting child benefits to poor families or to poor and middle-income families and, at the same time, curtailing coverage of wealthier families. In parallel, child benefits in both developed and developing countries are increasingly conditional on school enrollment, regular school attendance and/or compliance with other conditions on behalf of the benefit recipient families.

The child benefits are predominantly tax-financed schemes ${ }^{19}$. Eligible usually are children who are citizens, or permanent or habitual residents of the respective country, living in the country and being raised in a family or household which are responsible for raising and maintaining them. The most common age limit is 18 with possibilities to prolong the receipt of the child benefit if the child remains in education or training. There could be variations in the benefit amounts depending on the number of children in the family, their age and/or birth order. Higher benefit amounts and higher age limits for child benefit receipt exist when the child is an orphan or with special needs. Child benefits for children with special needs are not subject to means-test. Some of the legal regulations explicitly point at the child benefit should be paid to the mother, or to the family member who takes care of the child (usually the mother) ${ }^{20}$.

\footnotetext{
17 The set of measures includes, apart from cash payments, also tax reliefs, maternity, paternity and parental or child-raising leaves, school start allowances, childcare services, health and education services, housing, utility, sanitation and other public services related to children.

${ }^{18}$ Austria provides a monthly supplement to the child benefit for the third and subsequent children in families which are identified as poor based on their income. Also, in Austria, if a child eligible for child benefit has reached 19 years of age and has own income above certain threshold, this income is subtracted from the benefit. Belgium pays a "social supplement" to the child benefit for low-income categories - parents who are pensioners, recipients of unemployment benefit or benefit as self-employed, also to single parents. Lithuania has a child benefit supplement for poor families.

19 Italy is the only EU Member State where the child benefit is financed by employers' and workers' contributions. In Austria and France, the financing is combined - social insurance contributions and taxes.

${ }^{20}$ When paid to the mother, the child benefit is considered a secure and independent source of income at times of family disruption and gives a degree of independence to women where resources are not shared. Evidence suggests that mothers spend the money directly on their children.
} 


\begin{tabular}{|c|c|c|c|c|c|c|}
\hline & Basic principles & Means test & $\begin{array}{l}\text { Variation } \\
\text { with } \\
\text { income }\end{array}$ & $\begin{array}{c}\text { Variation } \\
\text { with birth } \\
\text { order and } \\
\text { number of } \\
\text { children }\end{array}$ & $\begin{array}{l}\text { Variation } \\
\text { with child's } \\
\text { age }\end{array}$ & Other provisions \\
\hline \multicolumn{7}{|c|}{ Western Balkan countries } \\
\hline Albania & $\begin{array}{l}\text { No specific child } \\
\text { benefit scheme }\end{array}$ & & & & & \\
\hline $\begin{array}{l}\text { Bosnia and } \\
\text { Herzegovina }\end{array}$ & $\begin{array}{l}\text { 1.Federation BiH: } \\
\text { financed from } \\
\text { cantonal budgets, } \\
\text { for employed and } \\
\text { unemployed } \\
\text { 2.Republika Srpska: } \\
\text { financed by the } \\
\text { republican Child } \\
\text { Fund, for all citizens } \\
\end{array}$ & $\begin{array}{l}\text { 1. Means- } \\
\text { tested } \\
\text { 2. Means } \\
\text { test, with } \\
\text { exempted } \\
\text { categories }\end{array}$ & $\begin{array}{l}\text { 1. No } \\
\text { 2. No }\end{array}$ & $\begin{array}{l}\text { 1. Flat rates } \\
\text { 2. Variation } \\
\text { by number of } \\
\text { children }\end{array}$ & $\begin{array}{l}\text { 1. No } \\
\text { 2. No }\end{array}$ & $\begin{array}{l}\text { 1. Child benefit rates } \\
\text { vary by cantons } \\
\text { 2.For the } 2^{\text {nd }} \text { thru } 4^{\text {th }} \\
\text { child. Paid to } 1^{\text {st }} \text { child if } \\
\text { with developmental } \\
\text { delay, orphan or comes } \\
\text { from family receiving } \\
\text { LRIS }\end{array}$ \\
\hline $\begin{array}{l}\text { North } \\
\text { Macedonia }\end{array}$ & $\begin{array}{l}\text { Tax-financed, for } \\
\text { economically active: } \\
\text { employed, farmers, } \\
\text { craftsmen, army } \\
\text { officers, also for } \\
\text { pensioners, war } \\
\text { veterans and } \\
\text { recipients of LRIS } \\
\end{array}$ & $\begin{array}{l}\text { Means } \\
\text { tested }\end{array}$ & No & $\begin{array}{l}\text { Flat rate for } \\
\text { each age } \\
\text { bracket }\end{array}$ & $\begin{array}{l}\text { Yes, two } \\
\text { tiers - for } \\
\text { up to } 15 \\
\text { years old } \\
\text { and for } 15- \\
18 \text { years old }\end{array}$ & $\begin{array}{l}\text { The benefit amount is } \\
\text { determined as } \\
\text { percentage of } \\
\text { minimum wage. Ceiling } \\
\text { on the benefit amount } \\
\text { regardless of number } \\
\text { of children or their age }\end{array}$ \\
\hline Montenegro & $\begin{array}{l}\text { Non-contributory, } \\
\text { state budget } \\
\text { financed. Eligible } \\
\text { are children in } \\
\text { families receiving } \\
\text { LRIS; care and } \\
\text { assistance } \\
\text { allowance, personal } \\
\text { disability allowance, } \\
\text { also orphans }\end{array}$ & $\begin{array}{l}\text { Yes, } \\
\text { indirectly - } \\
\text { beneficiaries } \\
\text { of means } \\
\text { tested LRIS }\end{array}$ & $\begin{array}{l}\text { No, but } \\
\text { rates vary } \\
\text { by type of } \\
\text { categorical } \\
\text { benefits } \\
\text { which } \\
\text { determine } \\
\text { eligibility }\end{array}$ & $\begin{array}{l}\text { Flat rate per } \\
\text { child, up to } 3 \\
\text { children in a } \\
\text { family }\end{array}$ & No & $\begin{array}{l}\text { Extended till the child } \\
\text { reaches } 18, \text { or above if } \\
\text { still in secondary } \\
\text { education. No means } \\
\text { test for disabled } \\
\text { children. Conditions for } \\
\text { receipt of LRIS, incl. } \\
\text { activation, apply to the } \\
\text { child benefit as well }\end{array}$ \\
\hline Serbia & $\begin{array}{l}\text { Non-contributory, } \\
\text { state budget } \\
\text { financed }\end{array}$ & $\begin{array}{l}\text { Means } \\
\text { tested; } \\
\text { separate } \\
\text { from LRIS } \\
\text { means test }\end{array}$ & No & $\begin{array}{l}\text { Flat rate paid } \\
\text { to up to } 4 \\
\text { children in a } \\
\text { family }\end{array}$ & No & $\begin{array}{l}\text { Administered by the } \\
\text { municipalities, not the } \\
\text { CSWs. Regional and } \\
\text { local governments can } \\
\text { provide top-ups }\end{array}$ \\
\hline \multicolumn{7}{|c|}{ EU and EFTA Member States } \\
\hline Austria & $\begin{array}{l}\text { 1.Universal scheme } \\
\text { financed by } \\
\text { employers' } \\
\text { contributions and } \\
\text { taxes } \\
\text { 2.Supplement for } \\
\text { the } 3^{\text {rd }} \text { and } \\
\text { subsequent } \\
\text { child(ren) in low } \\
\text { income families }\end{array}$ & $\begin{array}{l}\text { No } \\
\text { Exception } \\
\text { for child's } \\
\text { own income } \\
\text { after the } \\
\text { age of } 19\end{array}$ & $\begin{array}{l}\text { No } \\
\text { Income- } \\
\text { tested is } \\
\text { the } \\
\text { supplement }\end{array}$ & $\begin{array}{l}\text { Yes, increase } \\
\text { according to } \\
\text { "sibling } \\
\text { scales" }\end{array}$ & $\begin{array}{l}\text { Yes, } 3 \text { age } \\
\text { brackets }\end{array}$ & $\begin{array}{l}\text { Paid mainly to the } \\
\text { mother. Combined } \\
\text { with tax allowances for } \\
\text { families with } \\
\text { children/tax relief for } \\
\text { childcare }\end{array}$ \\
\hline Belgium & $\begin{array}{l}\text { 1.Compulsory social } \\
\text { insurance scheme } \\
\text { financed by a } \\
\text { federal grant }\end{array}$ & $\begin{array}{l}\text { 1. No } \\
\text { 2. Yes, } \\
\text { income- }\end{array}$ & $\begin{array}{l}\text { 1. No } \\
\text { 2. Yes }\end{array}$ & $\begin{array}{l}\text { 1. Yes } \\
\text { 2. Yes }\end{array}$ & $\begin{array}{l}\text { 1. No } \\
\text { 2. Yes }\end{array}$ & $\begin{array}{l}\text { Covers working } \\
\text { persons, self-employed } \\
\text { and civil servants. Paid } \\
\text { to the person raising }\end{array}$ \\
\hline
\end{tabular}




\begin{tabular}{|c|c|c|c|c|c|c|}
\hline & $\begin{array}{l}\text { 2.Social supplement } \\
\text { for parents who are } \\
\text { pensioners, receive } \\
\text { unemployment } \\
\text { benefit, benefit for } \\
\text { self-employed, or } \\
\text { single parents with } \\
\text { low income }\end{array}$ & $\begin{array}{l}\text { tested (and } \\
\text { categorical) }\end{array}$ & & & & $\begin{array}{l}\text { the child, usually the } \\
\text { mother. Regional } \\
\text { variations. Higher } \\
\text { benefit for orphans. } \\
\text { Tax rebates }\end{array}$ \\
\hline Bulgaria & $\begin{array}{l}\text { Tax-financed } \\
\text { system - monthly } \\
\text { allowance for } \\
\text { raising a child until } \\
\text { graduation from } \\
\text { high school, but not } \\
\text { after the age of } 20\end{array}$ & $\begin{array}{l}\text { Yes, income } \\
\text { test except } \\
\text { for orphans, } \\
\text { disabled } \\
\text { children, in } \\
\text { foster care }\end{array}$ & $\begin{array}{l}\text { Yes, three } \\
\text { income } \\
\text { groups / } \\
\text { levels }\end{array}$ & $\begin{array}{l}\text { Yes, increase } \\
\text { till } 4^{\text {th }} \text { child }\end{array}$ & No & $\begin{array}{l}\text { Regular school } \\
\text { attendance, } \\
\text { vaccinations and health } \\
\text { prophylactic controls. } \\
\text { Combined with tax } \\
\text { allowances }\end{array}$ \\
\hline Croatia & $\begin{array}{l}\text { Tax-financed } \\
\text { scheme covering all } \\
\text { residents }\end{array}$ & $\begin{array}{l}\text { Yes, income } \\
\text { test }\end{array}$ & $\begin{array}{l}\text { Yes, three } \\
\text { income } \\
\text { groups / } \\
\text { levels }\end{array}$ & $\begin{array}{l}\text { Flat rate per } \\
\text { income } \\
\text { bracket }\end{array}$ & No & $\begin{array}{l}\text { Parents of children } \\
\text { absent from Croatia for } \\
\text { more than } 3 \text { months } \\
\text { are not eligible. } \\
\text { Conditional to school } \\
\text { enrollment. Income tax } \\
\text { deductions }\end{array}$ \\
\hline Cyprus & $\begin{array}{l}\text { Tax-financed } \\
\text { scheme }\end{array}$ & $\begin{array}{l}\text { Yes, total } \\
\text { gross } \\
\text { income and } \\
\text { household } \\
\text { assets }\end{array}$ & $\begin{array}{l}\text { Yes, four } \\
\text { income } \\
\text { groups / } \\
\text { levels }\end{array}$ & $\begin{array}{l}\text { Variations by } \\
\text { birth order } \\
\text { and income } \\
\text { brackets }\end{array}$ & No & $\begin{array}{l}\text { Families with } 1 \text { or } 2 \\
\text { children are paid } \\
\text { annually; families with } \\
3 \text { or more children are } \\
\text { paid monthly. } \\
\text { Additional entitlement } \\
\text { to childcare }\end{array}$ \\
\hline $\begin{array}{l}\text { Czech } \\
\text { Republic }\end{array}$ & $\begin{array}{l}\text { 1.Tax financed } \\
\text { scheme for } \\
\text { qualifying residents } \\
2 . \text { Increased amount } \\
\text { in case of low } \\
\text { income from work } \\
\text { or receipt of } \\
\text { sickness benefits, } \\
\text { unemployment } \\
\text { benefits, or care } \\
\text { allowance }\end{array}$ & $\begin{array}{l}\text { Yes, income } \\
\text { test }\end{array}$ & $\begin{array}{l}\text { Yes, two } \\
\text { rates / } \\
\text { income } \\
\text { levels }\end{array}$ & $\begin{array}{l}\text { Flat rate } \\
\text { varying with } \\
\text { age }\end{array}$ & Yes & $\begin{array}{l}\text { The child should be in } \\
\text { full-time education at } \\
\text { secondary school or } \\
\text { university. Tax credit } \\
\text { for childcare in the } \\
\text { form of tax }\end{array}$ \\
\hline Denmark & $\begin{array}{l}\text { Tax financed } \\
\text { scheme covering all } \\
\text { residents } \\
\text { 1.Child and Youth } \\
\text { Benefit } \\
\text { 2.Child Allowance }\end{array}$ & Yes & $\begin{array}{l}\text { Yes, }(1) \text { is } \\
\text { reduced for } \\
\text { families } \\
\text { with higher } \\
\text { income }\end{array}$ & $\begin{array}{l}\text { 1. Flat rate } \\
\text { 2. Flat rate }\end{array}$ & $\begin{array}{l}\text { 1. Yes, } 4 \text { age } \\
\text { brackets } \\
\text { 2. No }\end{array}$ & $\begin{array}{l}\text { For (1), the parent with } \\
\text { parental authority must } \\
\text { pay taxes in Denmark. } \\
\text { Paid mainly to the } \\
\text { mother - monthly (1) } \\
\text { or quarterly (2) }\end{array}$ \\
\hline Estonia & $\begin{array}{l}\text { Tax financed } \\
\text { schemes } \\
\text { 1.Universal child } \\
\text { benefit } \\
\text { 2.Child care } \\
\text { allowance - for all } \\
\text { children up to 3, } \\
\text { and from } 3 \text { to } 8 \text { in } \\
\text { certain cases } \\
\end{array}$ & No & No & $\begin{array}{l}\text { Same rate for } \\
1^{\text {st }} \text { and } 2^{\text {nd }} \\
\text { child; same } \\
\text { higher rate } \\
\text { for } 3^{\text {rd }} \text { and } 4^{\text {th }} \\
\text { child. } \\
\text { Allowance for } \\
\text { large families }\end{array}$ & No & $\begin{array}{l}\text { Tax credits. The child } \\
\text { care allowance } \\
\text { becomes payable after } \\
\text { the end of the } \\
\text { maternity benefit, the } \\
\text { parental benefit and } \\
\text { the adoptive benefit for } \\
\text { the same child }\end{array}$ \\
\hline Finland & $\begin{array}{l}\text { Tax financed } \\
\text { universal scheme }\end{array}$ & No & No & $\begin{array}{l}\text { Increase with } \\
\text { birth order, } \\
\text { addition for }\end{array}$ & No & $\begin{array}{l}\text { All children ( } 10 \text { months } \\
-6 \text { years) are eligible } \\
\text { for municipal childcare }\end{array}$ \\
\hline
\end{tabular}




\begin{tabular}{|c|c|c|c|c|c|c|}
\hline & & & & $\begin{array}{l}\text { single } \\
\text { parents }\end{array}$ & & $\begin{array}{l}\text { Cash benefits for home } \\
\text { care or private daycare. } \\
\text { Temporary tax credits } \\
\text { for low income families } \\
\text { in } 2015 \text {-17 fiscal years }\end{array}$ \\
\hline France & $\begin{array}{l}\text { Universal scheme } \\
\text { financed by } \\
\text { contributions from } \\
\text { employers, self- } \\
\text { employed and from } \\
\text { a portion of the } \\
\text { generalized social } \\
\text { contribution }\end{array}$ & Yes & $\begin{array}{l}\text { Since July } \\
2015, \text { the } \\
\text { allowances } \\
\text { are } \\
\text { reduced for } \\
\text { families } \\
\text { with a high } \\
\text { income }\end{array}$ & $\begin{array}{l}\text { Variation } \\
\text { with number } \\
\text { of children }\end{array}$ & $\begin{array}{l}\text { Yes, age } \\
\text { supplement }\end{array}$ & $\begin{array}{l}\text { Paid for at least } 2 \\
\text { dependent children. } \\
\text { Tax reliefs. Supplement } \\
\text { for Child Care. Early } \\
\text { childhood benefit - } \\
\text { partial payment of care } \\
\text { costs for children } \\
\text { younger than } 6 . \\
\text { Depends on income, } \\
\text { age and number of } \\
\text { children and type of } \\
\text { chosen child care }\end{array}$ \\
\hline Germany & $\begin{array}{l}\text { Tax-financed } \\
\text { scheme for general } \\
\text { taxpayers who are } \\
\text { resident in } \\
\text { Germany or are } \\
\text { liable to income tax }\end{array}$ & No & No & $\begin{array}{l}\text { Variation } \\
\text { with birth } \\
\text { order }\end{array}$ & No & $\begin{array}{l}\text { Tax allowances for } \\
\text { families with children / } \\
\text { tax breaks for childcare } \\
\text { are available }\end{array}$ \\
\hline Greece & $\begin{array}{l}\text { Tax-financed } \\
\text { scheme }\end{array}$ & Yes & $\begin{array}{l}\text { Yes, three } \\
\text { income } \\
\text { groups / } \\
\text { levels }\end{array}$ & $\begin{array}{l}\text { Flat rate for } \\
\text { the } 1^{\text {st }} \text { and } \\
2^{\text {nd }} \text { child; } \\
\text { increased flat } \\
\text { rate for } 3^{\text {rd }} \\
\text { and next } \\
\text { child }\end{array}$ & No & $\begin{array}{l}\text { Legal and permanent } \\
\text { residence in Greece for } \\
\text { at least } 5 \text { years before } \\
\text { the year of submission } \\
\text { of application. Tax } \\
\text { allowances for families } \\
\text { with children/ tax relief } \\
\text { for childcare }\end{array}$ \\
\hline Hungary & $\begin{array}{l}\text { Tax financed } \\
\text { universal scheme }\end{array}$ & No & No & $\begin{array}{l}\text { Variation } \\
\text { with number } \\
\text { of children - } \\
\text { increase till } \\
3^{\text {rd }} \text { child }\end{array}$ & No & $\begin{array}{l}\text { Supplements for } \\
\text { disabled children, } \\
\text { single parents, poor } \\
\text { pensioners, foster } \\
\text { parents. Tax allowances } \\
\text { for families with } \\
\text { children }\end{array}$ \\
\hline Iceland* & $\begin{array}{l}\text { No cash child } \\
\text { benefit } \\
\text { Only tax refund }\end{array}$ & $\begin{array}{l}\text { Yes, for the } \\
\text { tax refund } \\
\text { taxable } \\
\text { income of } \\
\text { parents is } \\
\text { counted }\end{array}$ & No & Yes & No & $\begin{array}{l}\text { For living legally in } \\
\text { Iceland and subject to } \\
\text { taxation of income } \\
\text { from employment or } \\
\text { insured }\end{array}$ \\
\hline Ireland & $\begin{array}{l}\text { Tax financed } \\
\text { scheme }\end{array}$ & No & No & $\begin{array}{l}\text { Flat rate per } \\
\text { child }\end{array}$ & No & $\begin{array}{l}\text { Children should be } \\
\text { under } 18 \text { and in full- } \\
\text { time education. Benefit } \\
\text { is paid on first place to } \\
\text { the mother or step- } \\
\text { mother. Early } \\
\text { Childhood Care and } \\
\text { Education Scheme for } \\
\text { early childhood care } \\
\text { and education for } \\
\text { children in pre-school }\end{array}$ \\
\hline Italy & $\begin{array}{l}\text { Earnings-related } \\
\text { benefit for the } \\
\text { family, financed }\end{array}$ & $\begin{array}{l}\text { Yes, } \\
\text { counted is }\end{array}$ & $\begin{array}{l}\text { Yes, } 3 \\
\text { income } \\
\text { groups }\end{array}$ & $\begin{array}{l}\text { Variation } \\
\text { with income } \\
\text { and }\end{array}$ & No & $\begin{array}{l}\text { Child-raising } \\
\text { vouchers for additional } \\
\text { expenses of raising }\end{array}$ \\
\hline
\end{tabular}




\begin{tabular}{|c|c|c|c|c|c|c|}
\hline & $\begin{array}{l}\text { mainly by the } \\
\text { employers' } \\
\text { contributions and } \\
\text { also partly by } \\
\text { workers' } \\
\text { contributions }\end{array}$ & $\begin{array}{l}\text { household } \\
\text { income }\end{array}$ & & $\begin{array}{l}\text { composition } \\
\text { of family unit }\end{array}$ & & $\begin{array}{l}\text { children (baby-sitting } \\
\text { or other child care } \\
\text { services) within } 11 \\
\text { months following the } \\
\text { compulsory maternity } \\
\text { leave and as an } \\
\text { alternative to optional } \\
\text { supplementary } \\
\text { parental leave. Tax } \\
\text { deductions for family } \\
\text { expenses (childcare, } \\
\text { university fees) }\end{array}$ \\
\hline Latvia & $\begin{array}{l}\text { Tax-financed } \\
\text { universal scheme }\end{array}$ & No & No & $\begin{array}{l}\text { Increase with } \\
\text { birth order }\end{array}$ & No & $\begin{array}{l}\text { Supplements for } \\
\text { families with } 2 \text { and } \\
\text { more children }\end{array}$ \\
\hline Liechtenstein & $\begin{array}{l}\text { Compulsory, } \\
\text { contribution- } \\
\text { financed social } \\
\text { security scheme for } \\
\text { residents or } \\
\text { employed in } \\
\text { Liechtenstein }\end{array}$ & No & No & $\begin{array}{l}\text { Flat rate for } \\
1^{\text {st }} \text { and } 2^{\text {nd }} \\
\text { child; } \\
\text { increased flat } \\
\text { rate for next } \\
\text { children }\end{array}$ & $\begin{array}{l}\text { Yes, } \\
\text { supplement } \\
\text { for each } \\
\text { child over } \\
10 \text { years old }\end{array}$ & $\begin{array}{l}\text { If both parents are } \\
\text { entitled to benefits, the } \\
\text { payment is made to the } \\
\text { parent who primarily } \\
\text { cares for the child and } \\
\text { in whose household he } \\
\text { or she lives }\end{array}$ \\
\hline Lithuania & $\begin{array}{l}\text { 1.Tax-financed } \\
\text { universal scheme } \\
\text { with benefits for all } \\
\text { residents } \\
\text { 2. Means-tested } \\
\text { benefit for poor } \\
\text { families with } \\
\text { children }\end{array}$ & $\begin{array}{l}\text { 1. No } \\
\text { 2. Yes }\end{array}$ & $\begin{array}{l}\text { 1. No } \\
\text { 2. Yes }\end{array}$ & $\begin{array}{l}\text { 1. No } \\
\text { 2. Yes }\end{array}$ & $\begin{array}{l}\text { 1. No } \\
\text { 2. Yes }\end{array}$ & $\begin{array}{l}\text { Tax allowances for } \\
\text { families with } \\
\text { children/tax relief for } \\
\text { childcare }\end{array}$ \\
\hline Luxemburg & $\begin{array}{l}\text { Universal tax- } \\
\text { financed scheme }\end{array}$ & No & No & $\begin{array}{l}\text { Flat rate per } \\
\text { child }\end{array}$ & $\begin{array}{l}\text { Yes, age } \\
\text { supplement }\end{array}$ & $\begin{array}{l}\text { Tax relief for families } \\
\text { with children and for } \\
\text { childcare costs }\end{array}$ \\
\hline Malta & $\begin{array}{l}\text { A universal system } \\
\text { financed by general } \\
\text { taxation providing } \\
\text { an earnings-related } \\
\text { allowance }\end{array}$ & Yes & Yes & $\begin{array}{l}\text { Flat rate per } \\
\text { child }\end{array}$ & Yes & $\begin{array}{l}\text { For Maltese citizens } \\
\text { whose children reside } \\
\text { in Malta. On first place, } \\
\text { the benefit is paid to } \\
\text { the mother }\end{array}$ \\
\hline Norway & $\begin{array}{l}\text { Tax financed } \\
\text { universal scheme } \\
\text { providing a flat-rate } \\
\text { benefit for all } \\
\text { children }\end{array}$ & No & No & $\begin{array}{l}\text { Flat rate per } \\
\text { child }\end{array}$ & $\begin{array}{l}\text { No, except } \\
\text { for an infant } \\
\text { supplement }\end{array}$ & $\begin{array}{l}\text { Infant supplement for } \\
\text { single parents with } \\
\text { child/ren under } 3 \\
\text { years. Cash-for-care- } \\
\text { benefit - universal and } \\
\text { tax financed. Tax relief } \\
\text { for childcare }\end{array}$ \\
\hline Poland & $\begin{array}{l}\text { Tax-financed } \\
\text { scheme which } \\
\text { includes: } \\
\text { 1. Family allowance } \\
\text { 2.Benefit for child } \\
\text { raising } 500 \text { Plus }\end{array}$ & $\begin{array}{l}\text { 1. Yes } \\
2 . \text { No, but } \\
\text { no benefit is } \\
\text { paid for the } \\
1^{\text {st }} \text { or only } \\
\text { child if } \\
\text { income per } \\
\text { capita } \\
\text { exceeds a } \\
\text { threshold }\end{array}$ & $\begin{array}{l}\text { 1. Yes } \\
\text { 2. No, } \\
\text { except in } \\
\text { the case of } \\
1^{\text {st }} \text { or only } \\
\text { child }\end{array}$ & $\begin{array}{l}\text { 1. Flat rate } \\
\text { per child } \\
\text { 2. Flat rate } \\
\text { per child }\end{array}$ & $\begin{array}{l}\text { 1. Yes, } 3 \text { age } \\
\text { brackets } \\
\text { 2. No }\end{array}$ & $\begin{array}{l}\text { 1. From } 1 \text { January } \\
2016 \text {, families with } \\
\text { income a little above } \\
\text { the threshold can } \\
\text { receive allowance. Tax } \\
\text { relief for childcare } \\
2 \text {. If income is low } \\
\text { ( } € 183 \text { net per person), } \\
500 \text { Plus is paid for the } \\
1 \text { st or only child }\end{array}$ \\
\hline
\end{tabular}




\begin{tabular}{|c|c|c|c|c|c|c|}
\hline Portugal & $\begin{array}{l}\text { Compulsory } \\
\text { universal protection } \\
\text { system financed by } \\
\text { taxes }\end{array}$ & $\begin{array}{l}\text { Yes, income } \\
\text { and value of } \\
\text { movable } \\
\text { assets }\end{array}$ & $\begin{array}{l}\text { Yes, } 5 \\
\text { income or } \\
\text { earning } \\
\text { levels }\end{array}$ & $\begin{array}{l}\text { Variation } \\
\text { with family } \\
\text { composition, } \\
\text { income and } \\
\text { child age }\end{array}$ & Yes & $\begin{array}{l}\text { Subsidy for nurseries } \\
\text { with assistance based } \\
\text { on household income. } \\
\text { Tax relief for families } \\
\text { with children/tax relief } \\
\text { for childcare costs }\end{array}$ \\
\hline Romania & $\begin{array}{l}\text { Tax-financed } \\
\text { schemes with cash } \\
\text { and in-kind } \\
\text { benefits: } \\
\text { 1.State Allowance } \\
\text { for Children } \\
\text { 2.Family Support } \\
\text { Allowance }\end{array}$ & $\begin{array}{l}\text { 1.No } \\
\text { 2.Yes, } \\
\text { household } \\
\text { income }\end{array}$ & $\begin{array}{l}\text { 1.No } \\
\text { 2.Yes, } 3 \\
\text { income } \\
\text { levels }\end{array}$ & $\begin{array}{l}\text { 1.Flat rate } \\
\text { per child } \\
\text { 2.Flat rate } \\
\text { per child per } \\
\text { income level }\end{array}$ & $\begin{array}{l}\text { 1. No } \\
\text { 2. Yes }\end{array}$ & $\begin{array}{l}\text { Family Support } \\
\text { Allowance (2) is } \\
\text { conditional to regular } \\
\text { school attendance and } \\
\text { no misconduct. Tax } \\
\text { deductions for families } \\
\text { with children }\end{array}$ \\
\hline Slovakia & $\begin{array}{l}\text { Tax financed } \\
\text { universal scheme } \\
\text { providing flat-rate } \\
\text { benefits and } \\
\text { covering all } \\
\text { residents with } \\
\text { dependent } \\
\text { child/ren }\end{array}$ & No & No & $\begin{array}{l}\text { Flat rate per } \\
\text { child }\end{array}$ & $\begin{array}{l}\text { Supplement } \\
\text { for } \\
\text { pensioners } \\
\text { taking care } \\
\text { of a child }\end{array}$ & $\begin{array}{l}\text { Insurance -based Child } \\
\text { Care Allowance for } \\
\text { child care expenses. } \\
\text { Child Tax Credit - } \\
\text { universal scheme, flat } \\
\text { rate deduction, high- } \\
\text { income families are } \\
\text { exempted }\end{array}$ \\
\hline Slovenia & $\begin{array}{l}\text { Tax financed } \\
\text { scheme }\end{array}$ & $\begin{array}{l}\text { Yes, } \\
\text { incomes and } \\
\text { assets of all } \\
\text { family } \\
\text { members }\end{array}$ & Yes & $\begin{array}{l}\text { Variation by } \\
\text { birth order - } \\
\text { increase till } \\
4^{\text {th }} \text { child }\end{array}$ & $\begin{array}{l}\text { Two rates: } \\
\text { before / in } \\
\text { primary } \\
\text { education } \\
\text { and in } \\
\text { secondary } \\
\text { education }\end{array}$ & $\begin{array}{l}\text { Reduction in payment } \\
\text { of nursery fees for } \\
\text { families with per capita } \\
\text { income below the } \\
\text { average wage. Tax } \\
\text { allowance for } \\
\text { dependent members }\end{array}$ \\
\hline Spain & $\begin{array}{l}\text { Tax financed non- } \\
\text { contributory benefit } \\
\text { scheme }\end{array}$ & $\begin{array}{l}\text { Yes, family } \\
\text { income and } \\
\text { number if } \\
\text { dependents }\end{array}$ & Yes & $\begin{array}{l}\text { Flat rate, } \\
\text { increased in } \\
\text { case of } \\
\text { disability }\end{array}$ & $\begin{array}{l}\text { Yes, only for } \\
\text { disabled } \\
\text { children }\end{array}$ & $\begin{array}{l}\text { Income from labor, } \\
\text { capital, economic } \\
\text { activities, assets and } \\
\text { rights of a contractual } \\
\text { nature is counted. No } \\
\text { income limit in case of } \\
\text { disabled child. Benefit } \\
\text { levels differentiated } \\
\text { based on disability } \\
\text { status. Tax allowances } \\
\text { for families with } \\
\text { children/tax relief for } \\
\text { childcare }\end{array}$ \\
\hline Sweden & $\begin{array}{l}\text { Tax financed, } \\
\text { compulsory and } \\
\text { universal scheme }\end{array}$ & No & No & $\begin{array}{l}\text { Flat rate child } \\
\text { allowance; } \\
\text { differentiated } \\
\text { large family } \\
\text { supplements }\end{array}$ & $\begin{array}{l}\text { Yes, regular } \\
\text { and } \\
\text { extended } \\
\text { child } \\
\text { allowance }\end{array}$ & $\begin{array}{l}\text { Extended Child } \\
\text { Allowance when the } \\
\text { child is over } 16 \text { but still } \\
\text { in compulsory } \\
\text { education; paid directly } \\
\text { to the child. Subsidy for } \\
\text { childcare }\end{array}$ \\
\hline Switzerland & $\begin{array}{l}\text { Federal level: } \\
\text { Scheme for } \\
\text { agricultural workers } \\
\text { and self-employed } \\
\text { farmers, financed } \\
\text { by contributions } \\
\text { and taxes } \\
\text { Cantonal level: } \\
\text { Schemes for (1) }\end{array}$ & $\begin{array}{l}\text { No, except } \\
\text { for cantonal } \\
\text { level ( } 2 \text { ) } \\
\text { benefit - } \\
\text { persons not } \\
\text { in paid } \\
\text { employment } \\
\text { which is }\end{array}$ & No & $\begin{array}{l}\text { Flat rates per } \\
\text { child }\end{array}$ & $\begin{array}{l}\text { No variation } \\
\text { with age, } \\
\text { except for } 3 \\
\text { cantons }\end{array}$ & $\begin{array}{l}\text { The federal schemes } \\
\text { pay higher benefits in } \\
\text { mountain regions } \\
\text { compared to lowland } \\
\text { regions. In principle the } \\
\text { payment is received by } \\
\text { the parent who works. } \\
\text { Tax deductions for } \\
\text { families and for }\end{array}$ \\
\hline
\end{tabular}




\begin{tabular}{|c|c|c|c|c|c|c|}
\hline & $\begin{array}{l}\text { employees and self- } \\
\text { employed not in } \\
\text { agriculture } \\
\text { (financed by } \\
\text { contributions) and } \\
\text { (2) for persons not } \\
\text { in paid employment } \\
\text { with low income } \\
\text { (financed by taxes) }\end{array}$ & $\begin{array}{l}\text { means } \\
\text { tested }\end{array}$ & & & & $\begin{array}{l}\text { childcare costs, both at } \\
\text { the federal and the } \\
\text { cantonal levels }\end{array}$ \\
\hline $\begin{array}{l}\text { The } \\
\text { Netherlands }\end{array}$ & $\begin{array}{l}\text { Tax financed } \\
\text { scheme for insured } \\
\text { persons: } \\
\text { 1.Child benefit } \\
\text { 2.Child-related } \\
\text { allowance }\end{array}$ & $\begin{array}{l}\text { 1. No } \\
\text { 2. Yes, } \\
\text { counted is } \\
\text { household } \\
\text { income, } \\
\text { assets and } \\
\text { composition }\end{array}$ & $\begin{array}{l}\text { 1. No } \\
\text { 2. Yes }\end{array}$ & $\begin{array}{l}\text { 1. Flat rate } \\
\text { per age } \\
\text { bracket } \\
\text { 2. Variation } \\
\text { with number } \\
\text { of children }\end{array}$ & $\begin{array}{l}\text { 1. Yes, } 3 \text { age } \\
\text { brackets } \\
\text { 2. Yes, } 3 \text { age } \\
\text { brackets }\end{array}$ & $\begin{array}{l}\text { Additional Child-related } \\
\text { allowance for single } \\
\text { parents. Means-tested } \\
\text { tax-financed childcare } \\
\text { allowance for parents } \\
\text { for cost of childcare. } \\
\text { Tax allowances for } \\
\text { families with children/ } \\
\text { tax relief for childcare }\end{array}$ \\
\hline $\begin{array}{l}\text { United } \\
\text { Kingdom }\end{array}$ & $\begin{array}{l}\text { Tax financed (non- } \\
\text { contributory) } \\
\text { system for all } \\
\text { parents }\end{array}$ & $\mathrm{No}$ & $\begin{array}{l}\text { No, but tax } \\
\text { charge in } \\
\text { case of high } \\
\text { family } \\
\text { income }\end{array}$ & $\begin{array}{l}\text { Yes, higher } \\
\text { rate for the } \\
\text { eldest child }\end{array}$ & Yes & $\begin{array}{l}\text { Complemented by } \\
\text { Child tax credit - tax } \\
\text { financed, non- } \\
\text { contributory, income- } \\
\text { related system, for all } \\
\text { parents }\end{array}$ \\
\hline
\end{tabular}

*No data in MISSOC, other online sources are used for reference: https://www.rsk.is/english/individuals/child-benefits/; and https://dendax.com/en/iceland-child-benefit.

Source: MISSOC database, extraction as of July 1, 2018 for EU ad EFTA countries, https://www.missoc.org/missocdatabase/comparative-tables/results/; MISSCEO database 2018 for Albania, Bosnia and Herzegovina, North Macedonia, Montenegro and Serbia, http://www.missceo.coe.int 